\title{
PENGARUH EKSTRAK ETANOL DAUN JAMBU AIR (Syzygium aqueum (Burm f.)Alston) TERHADAP GLUKOSA DARAH, UREUM DAN KREATININ TIKUS PUTIH (Rattus norvegicus)
}

\author{
Joni Tandi* \\ Sekolah Tinggi Ilmu Farmasi Pelita Mas (STIFA) Palu, Jalan Wolter Monginsidi 106 A Palu, \\ *Corresponding Author: jonitandi757@yahoo.com
}

\begin{abstract}
Diabetes mellitus with complications of Diabetic Nephropathy become one of the most common cause of endstage renal failure in the world. Impaired kidney function is measured by Glomerular Filtration Rate (GFR). Where the decline in GFR was followed by increased levels of blood glucose, urea and creatinine. This study aimed to determine whether there is the content of secondary metabolites in leaves of Sizygium aqueum leaf extract, at a dose of extract what impact the blood glucose, urea and creatinine levels of male rats and whether the water extract of guava leaves have an influence on the blood glucose, urea and creatinine white male rats. This study uses a randomized block design with six treatment groups consisting of five test animals. Group I was normal control (CMC Na suspension 0.5\%). Group II negative control (streptozotocin $40 \mathrm{mg} / \mathrm{kg}$ ). positive control group III (suspension glibenclamide). Group IV given guava leaf extract 100 $\mathrm{mg} / \mathrm{kg} \mathrm{BW}$. V group awarded guava leaf extract $200 \mathrm{mg} / \mathrm{kg} \mathrm{BW}$. Group VI given guava leaf extract $300 \mathrm{mg} / \mathrm{kg}$ $B W$. Treatment was given for 28 days and measured levels of blood glucose urea and creatinine on days 0,7 , 14, 21 and 28. The results showed nefroprotektif effect on all groups and most effective extract are a group of guava leaf extract $100 \mathrm{mg} / \mathrm{kg} \mathrm{BW}$ ).
\end{abstract}

Keywords: Diabetic nephropathy, urea, creatinine, Syzygium aqueum

\begin{abstract}
ABSTRAK
Diabetes Melitus dengan komplikasi Nefropati Diabetik menjadi salah satu penyebab terbanyak gagal ginjal stadium akhir di dunia. Gangguan fungsi ginjal tersebut diukur dengan Glomerular Filtration Rate (GFR). Dimana penurunan GFR diikuti dengan kenaikan kadar glukosa darah, ureum dan kreatinin darah. Penelitian ini bertujuan untuk mengetahui apakah terdapat kandungan metabolit sekunder pada daun ekstrak daun jambu air, pada dosis berapakah ekstrak memberikan pengaruh terhadap kadar glukosa darah, ureum dan kreatinin tikus putih jantan dan apakah ekstrak daun jambu air memiliki pengaruh terhadap kadar glukosa darah, ureum dan kreatinin tikus putih jantan. Penelitian ini menggunakan Rancangan Acak Kelompok dengan 6 kelompok perlakuan yang terdiri dari 5 ekor hewan uji. Kelompok I kontrol normal (suspensi $\mathrm{Na}$ CMC 0,5\%). Kelompok II kontrol negatif (streptozotocin $40 \mathrm{mg} / \mathrm{kg} \mathrm{BB}$ ). kelompok III kontrol positif (suspensi glibenklamid ). Kelompok IV diberikan ekstrak daun jambu air $100 \mathrm{mg} / \mathrm{kg}$ BB. Kelompok V diberikan ekstrak daun jambu air $200 \mathrm{mg} / \mathrm{kg}$ BB. Kelompok VI diberikan ekstrak daun jambu air $300 \mathrm{mg} / \mathrm{kg}$ BB. Perlakuan diberikan selama 28 hari dan dilakukan pengukuran kadar glukosa darah, ureum dan kreatinin pada hari ke-0, 7, 14, 21 dan 28. Hasil yang diperoleh menunjukkan adanya efek nefroprotektif pada semua kelompok ekstrak dan yang paling efektif adalah kelompok ekstrak daun jambu air $100 \mathrm{mg} / \mathrm{kg} \mathrm{bb}$ ).
\end{abstract}

Kata kunci : Nefropati diabetik, Ureum, Kreatinin, Syzygium aqueum 


\section{PENDAHULUAN}

Diabetes melitus (DM) merupakan sindrom metabolik paling umum di seluruh dunia yang dapat menyebabkan kematian. Penyakit ini muncul ketika insulin tidak cukup diproduksi atau insulin tidak dapat berfungsi dengan baik [1]. International Diabetes Federation (IDF) tahun 2015 menyebutkan bahwa sekitar 415 juta orang dewasa di seluruh dunia menderita diabetes. Selain 415 juta orang dengan diabetes IDF memperkirakan bahwa 318 orang mengalami gangguan toleransi glukosa [2].

DM menjadi permasalahan kesehatan di dunia karena tingginya tingkat morbiditas maupun mortalitas yang ditimbulkan akibat penyakit tersebut [3]. Tingginya tingkat kematian pada penderita diabetes terjadi tidak secara langsung akibat hiperglikemianya, tetapi berhubungan dengan komplikasi yang terjadi. Komplikasi DM terjadi karena kadar glukosa dalam darah tidak terkendali dengan baik sehingga menyebabkan timbulnya berbagai komplikasi baik mikrovaskuler maupun makrovaskuler [4].

Diabetes melitus (DM) yang tidak terkontrol dapat menyebabkan terjadinya berbagai macam komplikasi kronik. Komplikasi kronik tersebut berupa kelainan mikrovaskuler seperti nefropati diabetik. Nefropati diabetik merupakan penyakit ginjal atau kerusakan ginjal akibat komplikasi penyakit diabetes melitus. Komplikasi diabetes melitus dapat mengenai organ tubuh dan jaringan ginjal yang ditandai dengan hiperfiltrasi membran basal glomeruli karena penurunan filtrasi glomerulus [6]. Nefropati diabetik dialami oleh 30 sampai 40\% sampel diabetes melitus dan berakhir pada komplikasi serius. Bukti-bukti menunjukkan bahwa proteinurea pada penderita nefropati diabetik maupun nondiabetik sebisa mungkin harus dikurangi. Semakin besar penurunan proteinurea sejak dini, maka semakin baik outcome untuk ginjal dalam jangka panjang. Selain dari proses metabolisme gula darah, metabolisme protein ini akan menghasilkan ureum atau urea nitrogen (Urea N). Kenaikan kadar ureum dapat diakibatkan oleh masukan protein yang banyak. Zat kimia dalam ureum yang bersifat toksik yaitu guanidin,fenol, amin, urat, kreatinin dan asam hidroksi aromatik dan indikan [5]. Pemanfaatan bahan alam yang memiliki khasiat obat dan digunakan masyarakat sebagai obat tradisional, salah satu bahan alam yang digunakan sebagai obat tradisional tersebut adalah daun jambu air (Syzygium aqueum (Burm.f) Alston).

Berdasarkan uraian di atas maka peneliti tertarik untuk melakukan penelitian lebih lanjut, apakah ekstrak etanol daun jambu air mempunyai pengaruh terhadap kadar ureum dan kreatinin terhadap tikus induksi streptozotocin.

Tujuan penelitian ini adalah untuk Menguji efek antidiabetes ekstrak etanol daun jambu air (Syzygium aqueum (Burm.f) Alston) pada tikus putih jantan (Rattus norvegicus) yang diinduksi streptozotocin. Mengetahui pengaruh ekstrak etanol daun jambu air (Syzygium aqueum (Burm f.) Alston) terhadap kadar ureum dan kreatinin pada tikus putih jantan (Rattus norvegicus) yang diinduksi streptozotocin. Mengetahui dosis yang efektif dari ekstrak etanol daun jambu air (Syzygium aqueum (Burm.f) Alston) ) terhadap kadar glukosa, ureum kreatinin serta sebagai antidiabetes.

\section{BAHAN DAN METODE}

\section{Alat dan Bahan \\ Alat \\ Ayakan mesh nomor 40, Batang pengaduk, Bejana maserasi, Blender}


(Sharp), Cawan Porselin $75 \mathrm{ml}$, Corong kaca (Pyrex), Erlenmeyer (Pyrex), Gegep kayu, Gelas ukur (Pyrex), Gelas kimia (Pyrex), Glukometer (Accu Chek), Glukotest strip test (Accu Chek), Gunting (Kenko), Kandang hewan uji , Kaca arloji, Labu ukur (Schott Duran), Mortir dan Stamper, Pipet tetes, Photometer 5010 (Roche $\left.{ }^{\circledR}\right)$, Rak tabung reaksi, Rotary Vaccum Evaporator (Heidolph), Sentrifuge, Sonde oral, Spoit injeksi (One Med Health Care), Spoit oral (One Med Health Care), Spot plate, Tabung darah Effendrof, Tabung reaksi (Pyrex), Timbangan analitik (Ohaus), Timbangan gram, Waterbath (Thermostatic Water Bath).

\section{Bahan}

Air suling, Alkohol $70 \%$, Allumunium foil (Klin pak), Aqua Destilata (Aqua), Aqua Pro Injeksi (Otsuka), Asam klorida (Merck), Besi (III) klorida (Merck), Betadine, Citrate-buffer saline (Natrium Sitrat, Asam Sitrat), Daun Jambu Air (Syzygium aqueum (Burm.f) Alston), Etanol 96\% (Merck), Eter, Glibenklamid (PT. Indo Farma No.Reg GKL9520905004A2 ), Kapas (Pro medic), Kit kreatinin (Asam pikrat \& sodium hidroksida), Kit ureum, Kertas saring, Larutan $\mathrm{NaCl} 10 \%$, Larutan $\mathrm{NaCl} 0,9 \%$ (PT. Widara Bhakti), LiebermannBurchard, Serbuk Magnesium (Merck), $\mathrm{Na} \mathrm{CMC} 0,5 \%$, Natrium hidroksida (Merck), Pakan Standar, Pereaksi Dragendorf, Streptozotocin (Bio Word USA), Serbuk Magnesium P (Merck).

\section{Pembuatan Suspensi Glibenklamid}

Dosis Glibenklamid pada manusia dewasa adalah $5 \mathrm{mg}$ per hari, jika dikonversi pada tikus dengan berat $200 \mathrm{~g}$ adalah 0,018 maka dosis Glibenklamid untuk tikus adalah $0,45 \mathrm{mg} / \mathrm{kg}$ BB. Ditimbang serbuk glibenklamid yang setara dengan 3,6 mg kemudian disuspensi dalam Na CMC 0,5\% hingga $100 \mathrm{ml}$. kocok hingga homogen.

\section{Pembuatan Ekstrak Etanol Daun Jambu Air}

Simplisia daun jambu air ditimbang sebanyak 600 gram lalu dimaserasi dengan menggunakan pelarut etanol $96 \%$ sebanyak 9 liter selama 24 jam. kemudian dilakukan remaserasi dengan pergantian pelarut tiap 24 jam selama 2 hari. Ekstrak kemudian disaring menggunakan kertas saring. Filtrat 1, 2, dan 3 yang diperoleh digabungkan selanjutnya dipekatkan menggunakan Rotary Vaccum evaporator pada suhu $60 \quad{ }^{\circ} \mathrm{C}$ dan diuapkan menggunakan waterbath dengan suhu 60 ${ }^{\circ} \mathrm{C}$ hingga diperoleh ekstrak kental daun jambu air. Diperoleh bobot ekstrak kental sebesar 73 gram dengan presen ekstrak $14,2 \%$.

\section{Pembuatan larutan Streptozotocin}

Streptozotocin ditimbang sebanyak 0,32 gram lalu dilarutkan menggunakan citrate-buffer saline dengan $\mathrm{pH}$ 4,5 lalu diinduksikan pada tikus melalui intraperitoneal (ip). Dosis streptozotocin yakni $40 \mathrm{mg} / \mathrm{kg} \mathrm{BB}$.

\section{Analisis Data}

Data hasil pengukuran kadar glukosa, ureum dan kreatinin yang diperoleh dianalisis secara statistik dengan menggunakan One Way Anova pada taraf kepercayaan $95 \%$. Apabila ada perbedaan yang bermakna, maka dilakukan uji lanjut post hoc LSD.

\section{HASIL DAN PEMBAHASAN}

Pengujian pengaruh ekstrak etanol daun jambu air terhadap kadar glukosa, ureum dan kreatinin dengan uji praklinik menggunakan hewan uji tikus putih jantan sebanyak 30 ekor yang dibagi dalam 6 kelompok perlakuan dan masing-masing kelompok terdiri dari 5 ekor tikus. Kelompok perlakuan terdiri dari 3 
kelompok yaitu (kelompok 4) ekstrak etanol daun jambu air dosis $100 \mathrm{mg} / \mathrm{kg}$ $\mathrm{BB}$, (kelompok 5) ekstrak etanol daun jambu air $200 \mathrm{mg} / \mathrm{kg} \mathrm{BB}$, dan (kelompok 6) ekstrak etanol daun jambu air 300 $\mathrm{mg} / \mathrm{kg}$ BB. Selain kelompok perlakuan, juga menggunakan kelompok kontrol yang terdiri dari (kelompok 1) kontrol normal (sehat) yang diberi suspensi $\mathrm{Na}$ CMC 0,5\%, (kelompok 2) kontrol positif diberikan suspensi glibenklamid, dan (kelompok 3) kontrol negatif yang diberikan streptozotocin.

Kelompok kontrol normal (sehat) digunakan sebagai pemberian pembawa (Na CMC 0,5\%) yang digunakan sebagai pendispersi pada pembuatan suspensi bahan uji. Kelompok kontrol negatif digunakan untuk memastikan adanya peningkatan kadar kreatinin dan ureum akibat pemberian induksi streptozotocin. Kelompok positif diberikan suspensi glibenklamid yaitu sebagai pembanding antar kelompok perlakuan ekstrak. Penginduksi yang digunakan adalah streptozotocin. Diabetes melitus (DM) yang tidak terkontrol dapat menyebabkan terjadinya berbagai macam komplikasi kronik. Komplikasi kronik tersebut berupa kelainan mikrovaskuler seperti nefropati diabetik. Nefropati diabetik merupakan penyakit ginjal atau kerusakan ginjal akibat komplikasi penyakit diabetes melitus [7]. Resiko DM dan komplikasinya berhubungan dengan kadar berbagai macam zat dalam serum darah, beberapa di antaranya adalah kreatinin dan kalium.

\section{HASIL DAN PEMBAHASAN}

Tabel 1. Hasil Uji Fitokimia Ekstrak Etanol Daun Jambu Air

\begin{tabular}{lc}
\hline \multicolumn{1}{c}{ Pengujian } & Hasil \\
\hline Uji Flavonoid & + \\
Uji Polifenol & + \\
Uji Saponin & + \\
Uji Alkaloid & + \\
Uji Tanin & + \\
Uji Triterpenoid & - \\
Uji Steroid & - \\
\hline
\end{tabular}

Keterangan : (+) : mengandung golongan senyawa yang diuji

$(-)$ : tidak mengandung golongan senyawa yang diuji

Tabel 2. Rerata Kadar Glukosa Darah Tikus Putih Jantan Yang Diinduksi Streptozotocin Setelah Pemberian Ekstrak Etanol Daun Jambu Air

\begin{tabular}{|c|c|c|c|c|c|c|c|}
\hline \multicolumn{8}{|c|}{ Rerata \pm SD Kadar Glukosa Darah (mg/dL) } \\
\hline $\begin{array}{l}\text { Hari } \\
\text { ke- }\end{array}$ & $\begin{array}{c}\text { Kontrol } \\
\text { normal }\end{array}$ & Kontrol sakit & $\begin{array}{l}\text { Kontrol positif } \\
\text { (glibenklamid) }\end{array}$ & $\begin{array}{l}\text { Dosis } 100 \\
\mathrm{mg} / \mathrm{Kg} \mathrm{BB}\end{array}$ & $\begin{array}{c}\text { Dosis } 200 \\
\mathrm{mg} / \mathrm{Kg} \mathrm{BB} *\end{array}$ & $\begin{array}{l}\text { Dosis } 300 \\
\mathrm{mg} / \mathrm{Kg} \mathrm{BB}\end{array}$ & $\mathrm{P}$ \\
\hline 0 & $95 \pm 7,44$ & $82,75 \pm 3,26$ & $88 \pm 9,56$ & $80,5 \pm 2,06$ & $84 \pm 5,04$ & $81,75 \pm 6,75$ & 0,094 \\
\hline 7 & $87,25 \pm 5,71$ & $246,5 \pm 20,91$ & $363 \pm 20,98$ & $274,25 \pm 44,45$ & $313,25 \pm 86,77$ & $329,25 \pm 115,11$ & 0,001 \\
\hline 14 & $86 \pm 5,61$ & $227,25 \pm 34,18$ & $146 \pm 58,31$ & $131,25 \pm 17,87$ & $103,75 \pm 5,53$ & $149 \pm 52,20$ & 0,003 \\
\hline 21 & $85,25 \pm 5,06$ & $233 \pm 37,28$ & $116 \pm 20,06$ & $124,5 \pm 7,69$ & $124 \pm 13,15$ & $131,25 \pm 10,63$ & 0,000 \\
\hline 28 & $95,75 \pm 9,31$ & $194,5 \pm 8,38$ & $111,5 \pm 6,72$ & $120,25 \pm 16,57$ & $99,25 \pm 7,98$ & $141,25 \pm 34,82$ & 0,000 \\
\hline
\end{tabular}

Sumber : Data Primer 2016 
Pengaruh Ekstrak Etanol Daun Jambu Air (Syzygium aqueum (burm f.)Alston) terhadap Glukosa Darah, Ureum dan Kreatinin Tikus Putih (Rattus norvegicus)

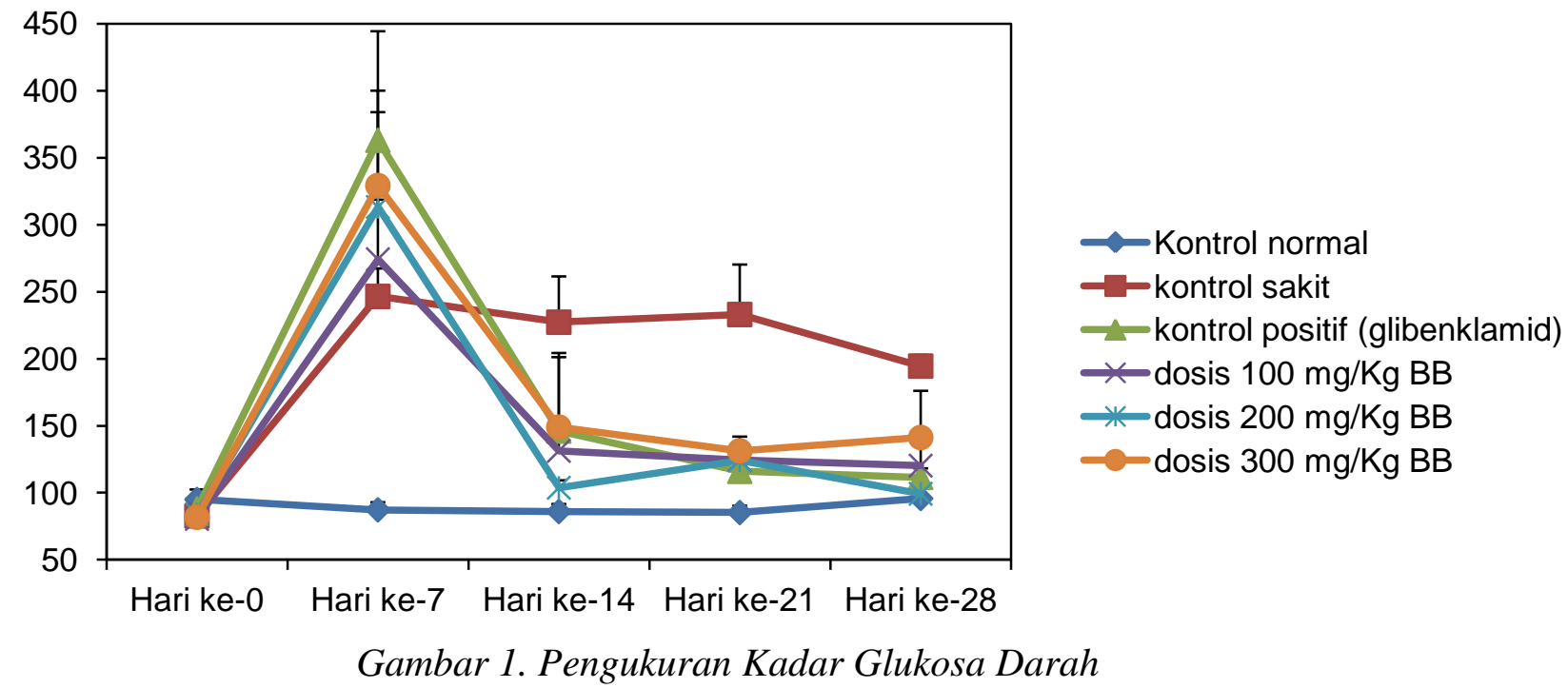

Tabel 3. $\quad$ Rerata Kadar Ureum Tikus Putih Jantan (Rattus norvegicus) Yang Di Induksi Streptozotocin dan Setelah Pemberian Ekstrak Daun Jambu Air (Syzygium aqueum (Burm f.) Alston)

\begin{tabular}{ccccccc}
\hline & \multicolumn{5}{c}{ Rerata Kadar Ureum (mg/dL) } \\
\hline \multirow{2}{*}{ Hari } & $\begin{array}{c}\text { Kontrol } \\
\text { normal }\end{array}$ & $\begin{array}{c}\text { Kontrol } \\
\text { negatif }\end{array}$ & $\begin{array}{c}\text { Kontrol } \\
\text { positif }\end{array}$ & $\begin{array}{c}\text { Dosis ekstrak } \\
\mathbf{1 0 0} \mathbf{~ m g} / \mathbf{k g ~ B B}\end{array}$ & $\begin{array}{c}\text { Dosis ekstrak } \\
\mathbf{2 0 0} \mathbf{~ m g} / \mathbf{k g ~ B B}\end{array}$ & $\begin{array}{c}\text { Dosis ekstrak } \\
\mathbf{3 0 0} \mathbf{~ m g} / \mathbf{k g ~ B B}\end{array}$ \\
\hline Hari ke-0 & 35,7 & 36,4 & 30,6 & 30,8 & 33,5 & 34,0 \\
Hari ke-7 & 35,8 & 36,68 & 37,6 & 36,92 & 36,6 & 39,86 \\
Hari ke-14 & 36,04 & 53,4 & 43,7 & 48,88 & 32,14 & 48,08 \\
Hari ke-21 & 36,2 & 56,08 & 54,9 & 41,7 & 40,4 & 56,7 \\
Hari ke-28 & 36,2 & 61,8 & 57,1 & 44,1 & 54,3 & 63,0 \\
\hline
\end{tabular}

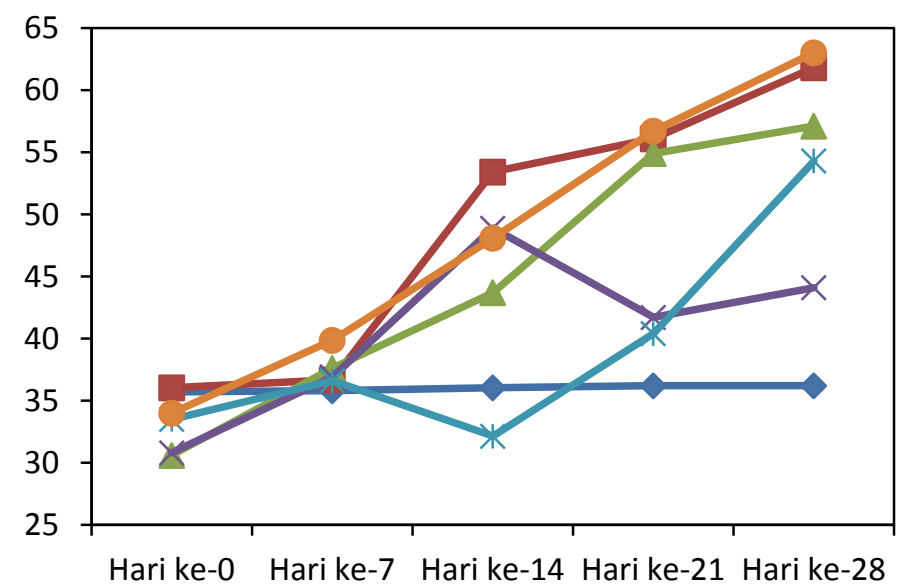

$\sim$ kontrol normal

- kontrol negatif

- kontrol positif

$\leftarrow$ dosis $100 \mathrm{mg} / \mathrm{kg} \mathrm{BB}$

* dosis $200 \mathrm{mg} / \mathrm{kg} \mathrm{BB}$

-dosis $300 \mathrm{mg} / \mathrm{kg} \mathrm{BB}$

Gambar 2. Profil Kadar Kreatinin Sebelum Perlakuan (H-O), Setelah Induksi (H-7, H-14), dan Selama Perlakuan (H-21, H-28) 
Pengaruh Ekstrak Etanol Daun Jambu Air (Syzygium aqueum (burm f.)Alston) terhadap Glukosa Darah, Ureum dan Kreatinin Tikus Putih (Rattus norvegicus)

Tabel 4. Rerata Kadar Kreatinin Tikus Putih Jantan (Rattus norvegicus) Yang Di Induksi Streptozotocin dan Setelah Pemberian Ekstrak Daun Jambu Air (Syzygium aqueum (Burmf.) Alston)

\begin{tabular}{ccccccc}
\hline \multirow{2}{*}{ Hari } & \multicolumn{7}{c}{ Rerata Kadar Kreatinin (mg/dL) } \\
\cline { 2 - 7 } & $\begin{array}{c}\text { Kontrol } \\
\text { normal }\end{array}$ & $\begin{array}{c}\text { Kontrol } \\
\text { negatif }\end{array}$ & $\begin{array}{c}\text { Kontrol } \\
\text { positif }\end{array}$ & $\begin{array}{c}\text { Dosis ekstrak } \\
\mathbf{1 0 0} \mathbf{~ m g / k g ~ B B}\end{array}$ & $\begin{array}{c}\text { Dosis ekstrak } \\
\mathbf{2 0 0} \mathbf{~ m g} / \mathbf{k g ~ B B}\end{array}$ & $\begin{array}{c}\text { Dosis ekstrak } \\
\mathbf{3 0 0} \mathbf{~ m g} / \mathbf{k g ~ B B}\end{array}$ \\
\hline Hari ke -0 & 0,73 & 0,76 & 0,74 & 0,70 & 0,69 & 0,65 \\
Hari ke -7 & 0,72 & 0,71 & 0,79 & 0,80 & 0,76 & 0,79 \\
Hari ke-14 & 0,73 & 0,70 & 0,66 & 0,59 & 0,58 & 0,67 \\
Hari ke-21 & 0,73 & 0,70 & 0,60 & $0,52^{*}$ & 0,52 & 0,65 \\
Hari ke-28 & 0,74 & 0,62 & 0,64 & $0,50 *$ & 0,65 & 0,69 \\
\hline
\end{tabular}

Keterangan : * terdapat perbedaan signifikan

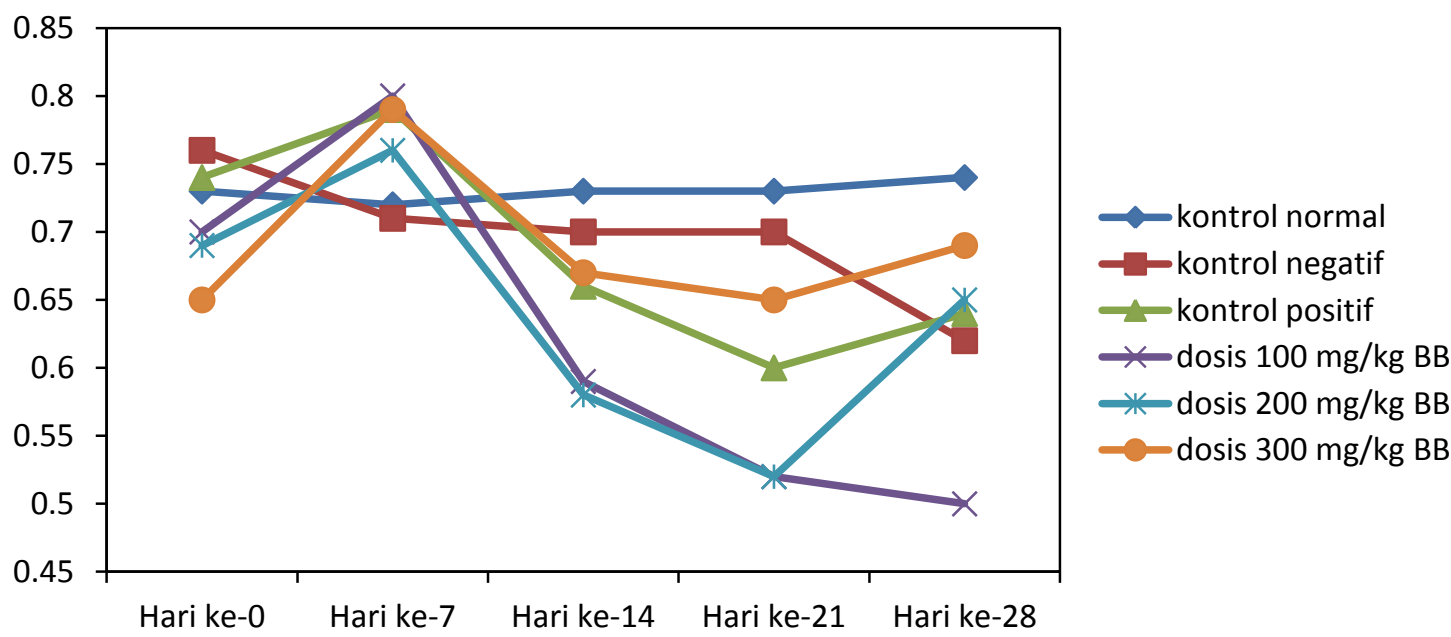

Gambar 3. Profil Kadar Ureum Sebelum Perlakuan (H-O), Setelah Induksi (H-7, H-14), dan Selama Perlakuan $(\mathrm{H}-2 \mathrm{l}, \mathrm{H}-28)$

Komplikasi diabetes melitus dapat mengenai organ tubuh dan jaringan ginjal yang ditandai dengan hiperfiltrasi membran basal glomeruli karena penurunan filtrasi glomerulus [8]. Bentuk komplikasi lain akibat diabetes melitus adalah Nefropati Diabetik yang ditandai dengan adanya kerusakan pada glomerolus, tubulus, jaringan interstisial dan vaskuler [9]. Nefropati diabetik ditandai dengan adanya mikroalbuminurea (30 $\mathrm{mg} / \mathrm{hari}$ atau $20 \mu \mathrm{g} / \mathrm{menit}$ ) tanpa adanya gangguan ginjal, disertai dengan peningkatan tekanan darah sehingga mengakibatkan menurunya filtrasi glomerolus dan akhirnya gagal ginjal tahap akhir.
Penelitian ini digunakan untuk melihat pengaruh pemberian ekstrak etanol daun jambu air terhadap kadar glukosa darah, ureum dan kreatinin adalah dengan mengukur kadar glukosa, kreatinin dan ureum tikus sebelum dan sesudah induksi yang diukur pada awal penelitian, setelah induksi streptozotocin, dan setelah perlakuan hari ke-14, 21 dan ke-28.

Analisis data dilakukan dengan menggunakan statistik one way Anova untuk melihat adanya perbedaan antar kelompok uji, jika terdapat perbedaan maka dilanjutkan dengan uji lanjut Post Hoc LSD. Hasil perhitungan rata-rata kadar kreatinin dan ureum tikus putih dapat dilihat pada Tabel 3 dan 4 . 
Penelitian ini diawali dengan pengukuran kadar kreatinin dan ureum awal (hari ke-0) untuk mengetahui kadar glukosa, kreatinin dan ureum normal tikus sebelum perlakuan.

Hasil statistik one way Anova kadar kreatinin pada hari ke-7 dan ke-14 menunjukkan bahwa tidak ada perbedaan yang bermakna antara semua kelompok perlakuan, hal ini dapat dilihat dari nilai $(\mathrm{P}>0,05)$ yaitu $\mathrm{P}<0,421$ dan $(\mathrm{P}>0,05)$ yaitu $\mathrm{P}<0,191$ sehingga tidak dilanjutkan dengan uji Post Hoc LSD untuk melihat perbedaan yang bermakna antar kelompok perlakuan.

Hasil statistik one way Anova glukosa darah pada hari ke-7 memperlihatkan nilai $\mathrm{P}=0,001 \quad(\mathrm{P}<0,05)$ yang menunjukkan terdapat perbedaan yang signifikan pada semua kelompok perlakuan, yang artinya ada efek pemberian streptozotocin kecuali pada kontrol normal, sehingga dilanjutkan dengan uji post hoc LSD untuk melihat perbedaan yang bermakna antar kelompok perlakuan, pada hari ke-14 memperlihatkan nilai $\mathrm{P}=0,003 \quad(\mathrm{P}<0,05)$ yang menunjukkan terdapat perbedaan yang signifikan pada semua kelompok perlakuan, yang artinya ada efek pemberian kontrol positif glibenklamid maupun ekstrak dosis $100 \mathrm{mg} / \mathrm{Kg} \mathrm{BB}, 200$ $\mathrm{mg} / \mathrm{kg} \mathrm{BB}$ dan $300 \mathrm{mg} / \mathrm{kg} \mathrm{BB}$, sehingga dilanjutkan dengan uji post hoc LSD untuk melihat perbedaan yang bermakna antar kelompok perlakuan, hari ke-21 memperlihatkan nilai $\mathrm{P}=0,000 \quad(\mathrm{P}<0,05)$ yang menunjukkan terdapat perbedaan yang signifikan pada semua kelompok perlakuan, yang artinya ada efek pemberian kontrol positif glibenklamid maupun ekstrak dosis $100 \mathrm{mg} / \mathrm{Kg} \mathrm{BB}, 200$ $\mathrm{mg} / \mathrm{kg}$ BB dan $300 \mathrm{mg} / \mathrm{kg} \mathrm{BB}$, sehingga dilanjutkan dengan uji post hoc LSD untuk melihat perbedaan yang bermakna antar kelompok perlakuan, dan pada hari ke-28 memperlihatkan nilai $\mathrm{P}=0,000$ $(\mathrm{P}<0,05)$ yang menunjukkan terdapat perbedaan yang signifikan pada semua kelompok perlakuan, yang artinya ada efek pemberian kontrol positif glibenklamid maupun ekstrak dosis 100 $\mathrm{mg} / \mathrm{Kg} \mathrm{BB}, 200 \mathrm{mg} / \mathrm{kg}$ BB dan $300 \mathrm{mg} / \mathrm{kg}$ $\mathrm{BB}$, sehingga dilanjutkan dengan uji post hoc LSD untuk melihat perbedaan yang bermakna antar kelompok perlakuan.

Hasil statistik one way Anova kadar kreatinin pada hari ke-21 menunjukkan bahwa adanya perbedaan yang bermakna antara beberapa kelompok perlakuan, hal ini dapat dilihat dari nilai $(\mathrm{P}<0,05)$ yaitu $\mathrm{P}<0,005$ sehingga dilanjutkan dengan uji Post Hoc LSD untuk melihat perbedaan yang bermakna antar kelompok perlakuan. Hasil uji Post Hoc LSD kadar kreatinin pada hari ke-21 menunjukkan bahwa pada kelompok kontrol normal berbeda signifikan dengan kontrol positif (glibenklamid), ekstrak $100 \mathrm{mg} / \mathrm{kg} \mathrm{BB}$ dan ekstrak $200 \mathrm{mg} / \mathrm{kg} \mathrm{BB}$, namun tidak berbeda signifikan dengan kontrol negatif (streptozotocin) dan ekstrak $300 \mathrm{mg} / \mathrm{kg}$ BB. Kemudian pada kelompok perlakuan negatif (streptozotocin) menunjukkan hasil yaitu berbeda signifikan dengan ekstrak $100 \mathrm{mg} / \mathrm{kg}$ BB dan ekstrak 200 $\mathrm{mg} / \mathrm{kg} \quad \mathrm{BB}$, namun tidak berbeda signifikan dengan kontrol normal ( $\mathrm{Na}$ CMC 0,5\%), positif (glibenklamid) serta kelompok ekstrak $300 \mathrm{mg} / \mathrm{kg} \quad \mathrm{BB}$. Sedangkan pada kelompok perlakuan kontrol positif (glibenklamid) berdasarkan hasil uji Post Hoc LSD menujukkan adanya perbedaan yang signifikan hanya pada kontrol normal saja namun tidak berbeda signifikan pada kontrol negatif (streptozotocin), ekstrak $100 \mathrm{mg} / \mathrm{kg} \mathrm{BB}$, $200 \mathrm{mg} / \mathrm{kg}$ BB serta ekstrak $300 \mathrm{mg} / \mathrm{kg}$ BB.

Hasil uji statistik one way Anova kadar kreatinin pada hari ke-28 menunjukkan adanya perbedaan yang signifikan antar beberapa kelompok perlakuan, hal ini dapat dilihat dari nilai $(\mathrm{P}<0,05) \quad$ yaitu $\quad \mathrm{P}<0,013 \quad$ sehingga 
dilanjutkan dengan uji Post Hoc LSD untuk melihat perbedaan yang bermakna antar kelompok perlakuan. Berdasarkan hasil uji Post Hoc LSD menunjukkan bahwa pada kontrol normal terdapat perbedaan yang signifikan terhadap kelompok perlakuan ekstrak $100 \mathrm{mg} / \mathrm{kg}$ $\mathrm{BB}$, namun tidak berbeda signifikan terhadap kelompok negatif (streptozotocin), kelompok positif (glibenklamid), kelompok ekstrak 200 $\mathrm{mg} / \mathrm{kg}$ BB dan ekstrak $300 \mathrm{mg} / \mathrm{kg}$ BB. Pada kelompok negatif (streptozotocin) berdasarkan hasil uji Post Hoc LSD menunjukkan bahwa tidak ada perbedaan yang signifikan pada semua kelompok. Sedangakan pada kontrol positif (glibenklamid) terdapat perbedaan yang signifikan terhadap kelompok ekstrak 100 $\mathrm{mg} / \mathrm{kg}$ BB dan tidak berbeda signifikan terhadap kelompok normal (Na CMC 0,5\%), negatif (streptozotin), ekstrak 200 $\mathrm{mg} / \mathrm{kg}$ BB serta ekstrak $300 \mathrm{mg} / \mathrm{kg}$ BB.

Hasil statistik one way Anova kadar ureum tikus putih jantan (Rattus norvegicus) pada hari ke-7, 14, 21 dan hari ke-28 menunjukkan bahwa tidak adanya perbedaan yang signifikan antara semua kelompok perlakuan, hal ini dapat dilihat dari nilai $(\mathrm{P}>0,05)$ yaitu $\mathrm{P}<0,986$, $(\mathrm{P}>0,05)$ yaitu $\mathrm{P}<0,071, \quad(\mathrm{P}>0,05)$ yaitu $\mathrm{P}<0,108$ dan $(\mathrm{P}>0,05)$ yaitu $\mathrm{P}<0,078$, sehingga tidak dilanjutkan dengan uji Post Hoc LSD untuk melihat perbedaan yang bermakna antar kelompok perlakuan. Hal ini dapat disebabkan oleh beberapa faktor internal maupun eksternal diantaranya yaitu asupan protein hewan uji yang dapat mempengaruhi parameter pengujian seperti ureum dan kreatinin.

Kelompok perlakuan yang diberikan ekstrak daun jambu air dengan 3 variasi dosis semuanya memiliki pengaruh terhadap kadar ureum dan kreatinin pada tikus diabetes. Kelompok perlakuan yang diberikan ekstrak daun jambu air dosis $100 \mathrm{mg} / \mathrm{kg} \mathrm{BB}, 200 \mathrm{mg} / \mathrm{kg} \mathrm{BB}$ dan 300 $\mathrm{mg} / \mathrm{kg}$ BB memilki efek yang sebanding dengan kontrol positif (glibenklamid) yang umum digunakan oleh penderita diabetes, akan tetapi dari ketiga dosis tersebut, dosis $100 \mathrm{mg} / \mathrm{kg} \mathrm{BB}$ memberikan penurunan terhadap kadar ureum dan kreatinin pada hewan uji yang mendekati ureum dan kreatinin kelompok normal dibanding dosis $200 \mathrm{mg} / \mathrm{kg}$ BB dan 300 $\mathrm{mg} / \mathrm{kg} \mathrm{BB}$ yang masih tergolong tinggi, berdasarkan hasil statistik maka dosis 100 $\mathrm{mg} / \mathrm{Kg} \mathrm{BB}$ merupakan dosis yang efektif dalam mempengaruhi dan menurunkan kadar ureum kreatinin hewan uji.

\section{KESIMPULAN}

Berdasarkan hasil penelitian dan pembahasan maka dapat disimpulkan beberapa hal sebagai berikut :

1. Ekstrak etanol daun jambu air (Syzygium aqueum (Burm.f) Alston) memiliki efek antidiabetes pada tikus yang diinduksi streptozotocin.

2. Pemberian esktrak daun jambu air (Syzygium aqueum (Burm f.) Alston) berpengaruh terhadap kadar ureum dan kreatinin tikus putih jantan (Rattus norvegicus) yang diinduksi streptozotocin.

3. Ekstrak daun jambu air dosis 200 $\mathrm{mg} / \mathrm{kg}$ BB merupakan dosis yang efektif untuk menurunkan kadar glukosa darah hingga ke batas normal dan sebanding dengan kontrol positif.

4. Ekstrak daun jambu air (Syzygium aqueum (Burm f.) Alston) dosis 100 $\mathrm{mg} / \mathrm{kg}$ BB efektif terhadap penurunan kadar ureum dan kreatinin tikus putih jantan (Rattus norvegicus) yang diinduksi streptozotocin yaitu dosis $100 \mathrm{mg} / \mathrm{kg} \mathrm{BB}$.

\section{SARAN}

1. Ekstrak etanol daun jambu air (Syzygium aqueum (Burm f.) Alston) dapat dijadikan modalitas terhadap terapi pada penderita nefropati 
diabetik namun masih memerlukan penelitian dengan rancangan penelitian yang lebih baik dan waktu penelitian yang lebih lama.

2. Perlu dilakukan uji klinis langsung terhadap penderita nefropati diabetik pada manusia

\section{DAFTAR PUSTAKA}

[1]. Watkins, PJ., Stephanie, AA., Simon,LH and Elieen, T. 2003. Diabetes and its management, 6 th ed. Blackwell Publishing. London. Hal. 5

[2]. Internasional Diabetes Federation. 2015. IDF Diabetes Atlas. Edisi 7. Hal 9, 17, 2829,51

[3]. Marianne, Yuandani, Rosnani. 2011. Antidiabetic Activity From Ethanol Extract of Kluwih's Leaf (Artocarpus Camansi). Vol. 11, No. 2 Fakultas Farmasi. Universitas Sumatera Utara. Hal 64.

[4]. Yuhelma, Fathra, AN., Yesi, H,. 2013. Identifikasi Dan Analisis Komplikasi Makrovaskuler Dan Mikrovaskuler Pada Pasien Diabetes Mellitus. Program Studi Ilmu Keperawatan. Universitas Riau. Hal 569-570.
[5]. Soeparman, et al. Ilmu Penyakit Dalam. Jakarta: Balai Penerbit FKUI; 1990

[6]. AADA (Acta American Diabetes Association). 2012. Diagnosis and Classification of Diabetes Mellitus. Diabetes Care 35 (1). Care-diabetesjournal-org.

[7]. Alfarisi S, Basuki W, Susantiningsih T.(2013) Perbedaan kadar kreatinin serum pasien diabetes melitus tipe-2 yang terkontrol dan yang tidak terkontrol di RSUD dr. H.Abdul Moelok Bandar Lampung tahun 2012. Majority, 2(5): 129136

[8]. Harahap, FH. 2014. Efek Pemberian Ekstrak Nigella sativa Terhadap Kadar Glukosa Darah dan Kolesterol Pada Tikus Diabetes Mellitus yang Diinduksi dengan Streptozotocin. Laporan Penelitian. Universitas Islam Negeri Syarif Hidayatullah. Jakarta. 7, 10

[9]. Rubenstein D,dkk. 2007. Lecture Notes: Kedokteran klinis. Edisi 6. Jakarta: Erlangga.

\section{How to cited this article :}

Tandi J. 2017. Pengaruh Ekstrak Etanol Daun Jambu Air (Syzygium aqueum (burm f.)Alston) terhadap Glukosa Darah, Ureum dan Kreatinin Tikus Putih (Rattus norvegicus), J. Trop.Pharm. Chem. 4(2); 43-51. 